\title{
Cold War Allies: Commonwealth and United States Naval Cooperation in Asian Waters
}

\section{Edward J. Marolda}

L'interaction entre les gouvernements canadiens, australiens, des ÉtatsUnis et du Royaume-Uni au cours de la guerre froide en Asie a été le plus souvent caractérisée par un désaccord sur les objectifs et la politique des États-Unis. Tel n'était pas le cas, cependant, avec l'expérience opérationnelle des marines de ces pays. En effet, les liens tissés entre les chefs des marines et des commandants de combat pendant les guerres de Corée et du Viêtnam ainsi que l'effort pour ramener la stabilité en Extrême-Orient, ont eu un impact positif sur la solidarité alliée et sur les mesures de sécurité collectives à la fin du 20ème et au 21ème siècles. Ce document traite de la nature de la relation opérationnelle entre les quatre marines dans la guerre de Corée; des actions navales américaines, britanniques et australiennes dans la gestion des conflits en Asie du SudEst au cours des années 50 et 60; l'expérience sous feu de la Marine royale australienne et la Marine américaine; et l'interaction vers la fin de la guerre froide pour faire face à la la présence et la montée en puissance de la marine soviétique dans les eaux asiatiques.

The navies of the United Kingdom, Canada, Australia, and New Zealand operated side by side with the navy of the United States throughout much of the Cold War in Asia. Despite often contentious policy disagreements between Washington and Commonwealth capitals, their navies functioned at high levels of coordination, interoperability, and efficiency. While the Korean War marked the high point of this interaction, the Royal Australian Navy fought off Vietnam with the U.S. Seventh Fleet and all of the Commonwealth navies took part in multinational exercises during the long Cold War. In this paper, the author addresses in detail the cooperation between the U.S. Navy and Commonwealth navies during the Korean war, with brief coverage of similar cooperation during the Vietnam War and the last years of the Cold War.

\section{Allied Naval Response to Communist Aggression \\ The Commonwealth and U.S. navies, allies in World War II, joined together once again in the first armed conflict of the so-called Cold War - the Korean War. Soon after North Korean Communist forces invaded the Republic of Korea on 25 June 1950, the United Nations Security Council voted in support of an armed response by member nations to the}

The Northern Mariner/Le marin du nord XXIV, Nos. 3 \& 4 (Jul. \& Oct. 2014), 214-234 Canadian Military History 23, Nos. 3 \& 4 (Summer \& Autumn 2014), 214-234 
attack. President Harry S. Truman directed the U.S. Seventh Fleet, then operating from Subic Bay in the Philippines, to steam for waters off the Asian continent. Admiral Arthur W. Radford, the Pacific Fleet commander, transferred operational control of the Seventh Fleet to Commander Naval Forces, Far East, Vice Admiral C. Turner Joy. The Seventh Fleet's first mission was to prevent the conflict in Korea from spreading throughout the Far East by warning Mao Tse-tung's Chinese Communist government in Beijing not to invade the island of Taiwan occupied by Chiang Kai-shek's Chinese Nationalist government. Aircraft carrier Valley Forge, heavy cruiser Rochester, and eight destroyers steamed just to the east of Taiwan and the carrier's planes made a show of force, flying in broad daylight between the island and the mainland of China. ${ }^{1}$

Once the UN voted to oppose the North Korean invasion, the call went out from Washington for naval support from Commonwealth and other navies. British light carrier Triumph, with Rear Admiral W.G. Andrewes embarked, was already deployed in the Far East as were several Royal Navy cruisers and destroyers, and these ships immediately headed for Korean waters. ${ }^{2}$

Before the end of June, the Australian government had assigned destroyer Bataan and frigate Shoalhaven, already operating in the region, to General Douglas MacArthur's UN command. In the apt words of Australian historian Alastair Cooper, the "prompt, effective, and sustained response to the American Government's initial appeal influenced U.S.Australian relations for many decades.",3

The Royal Canadian Navy soon joined the UN effort in Korea, but like the U.S. armed forces, was unprepared for the sudden war in Asia. The chief of naval staff in Ottawa sent a communication to the commander of the ships on the Pacific coast at Esquimalt as follows: "First at bat as usual. Good luck in your mission."4 The official Canadian history had a different take on the situation: "First at bat indeed - but only in the usual Canadian context! ... The crews of the destroyers were not even in the stadium, let alone in the 'On Deck' circle."5 Of the available destroyers, Sioux was in dry dock for maintenance, the crewmen of Athabaskan were on liberty, and Cayuga had just emerged from dry dock and

1 Information in this paper on the operations of the U.S. Navy in the Korean War is derived from the following sources: Malcolm W. Cagle and Frank A. Manson, The Sea War in Korea (Annapolis: Naval Institute Press, 1957); James A. Field, U.S. Naval Operations: Korea (Washington: Naval History Division, 1962); Edward J. Marolda (ed)., The U.S. Navy in the Korean War (Annapolis: Naval Institute Press, 2007); Edward J. Marolda, "U.S. Navy," and Richard P. Hallion, "Naval Air Operations in the Korean War," in Stanley Sandler (ed.), The Korean War: An Encyclopedia (New York: Garland Publishing Inc., 1995).

2 Anthony Farrar-Hockley, The British Part in the Korean War (London: HMSO, 1990), 44, 52.

3 Alastair Cooper, "The Korean War Era," in David Stevens (ed.), The Royal Australian Navy, Vol III in series, The Australian Centenary History of Defence (South Melbourne: Oxford University Press, 2001), 173.

4 Quoted in the commemorative official history by the Directorate of History and Heritage (DHH), Canada and the Korean War (Montreal: Art Global, 2002), Chapter 2: "First at Bat" [by Michael Whitby], 4.

5 "First at Bat," 1. 
needed to be loaded with stores. To bring the three ships up to wartime strength, the Canadian Navy stripped other ships and shore stations of personnel and supplies. Cayuga and Athabaskan, however, were the two newest ships in the navy and were equipped with advanced electronics. Sioux was a veteran of World War II operations but had been extensively modernized. ${ }^{6}$

Leading the three Korea-bound warships was Captain Jeffry V. Brock, Commander Canadian Destroyer Division Pacific. Characterized as a brash, cocksure naval officer, Brock proved to be an outstanding combat leader. A total of 3,621 sailors and all but three of Canada's eleven destroyers served in the Korean War, most on multiple tours. The pioneering three were followed by Huron, Iroquois, Nootka, Crusader, and Haida. As a demonstration of Ottawa's resolve to support Cold War operations in the Pacific, Canadian destroyers served in Far Eastern waters for two years after the Korean War to monitor compliance with the 27 July 1953 armistice agreement. ${ }^{7}$

Soon after war broke out on the Korean peninsula, New Zealand ordered the deployment there of two of the Royal New Zealand Navy's six frigates. Tutira and Pukaki reached the battle zone at the end of July and immediately joined other Commonwealth warships escorting carriers and bombarding targets ashore. ${ }^{8}$

\section{First Combat Operations}

U.S. and allied naval forces wasted little time seizing control of the seas around Korea and projecting naval power ashore. On 2 July, U.S. cruiser Juneau, British cruiser Jamaica, and British frigate Black Swan intercepted North Korean torpedo boats and motor gunboats off the east coast of the Republic of Korea and eliminated four of the Communist combatants. One week later, the British suffered their first casualties when North Korean shore fire hit Jamaica and killed a sailor and five temporarily embarked soldiers.

Valley Forge and Triumph and their escorts rendezvoused off Okinawa and prepared to attack targets in North Korea. The allies hit the ground running. Admiral Andrewes observed that "it all seemed familiar joining up in formation as it was just what we had done so often during the [joint] exercises in March with very similar forces." He added, "we didn't feel out of things and we were already getting back into the easy use of American signal books." 9 On 3 July, planes from Valley Forge and Triumph bombed Pyongyang, the capital and heart of the North Korean war machine. F9F Panthers from Valley Forge shot down a pair of North Korean MiGs, the first aerial victories for U.S. jet aircraft.

But an even more vital task was to prevent North Korean forces from conquering the entire peninsula and destroying the desperately fighting U.S. and UN ground forces. Allied cruisers and destroyers shelled enemy units moving along the coast as carrier-based air units

6 "First at Bat," 1.

7 "First at Bat," 2-3; DHH, Canada and the Korean War, Chap 8: "Islands and Packages" [by Michael Whitby].

8 G.F. Hopkins, Tales From Korea: The Royal New Zealand Navy in the Korean War (Auckland: Reed Books, 2002).

9 Quoted in Farrar-Hockley, The British Part in the Korean War, 64. 
struck Communist troops and supply convoys heading south on inland roads. The enemy hit back. A pair of North Korean Stormovik attack planes strafed British destroyer Comus west of Inchon on 23 August, killing a sailor and severely damaging the ship. Canadian Captain Brock expressed concern that his ships were not well armed to deal with the air threat, but increasing allied air superiority soon made that a moot point. ${ }^{10}$

In mid-July, British cruiser Belfast and destroyer Cossack joined with U.S. warships to delay the advance of North Korean troops on the east coast so the U.S. 1st Cavalry Division could land and take up defensive positions. British officers went ashore and coordinated their gunfire support procedures with the Americans, which almost immediately improved the accuracy of the naval bombardments. ${ }^{11}$

Admiral Joy, conscious that the Soviet Pacific Fleet operated a sizeable submarine force at Vladivostok, initially directed that UN naval forces attack any unidentified undersea vessel in the war zone. British and other U.S. leaders cautioned, however, that sinking a Soviet submarine might have dire consequences, so he limited anti-submarine attacks to the immediate vicinity of UN warships. The point again proved moot, because Soviet dictator Joseph Stalin, who had no desire to directly involve the USSR in hostilities so soon after World War II, strictly forbid his aircraft or naval vessels from attacking UN ships.

Admirals Joy and Andrewes met in Tokyo and decided on a division of naval labor off Korea. They determined that because the British and Commonwealth ships had similar operating procedures, training, and equipment, they should be grouped together. They also concluded that the U.S. ships should operate on the east coast because of the proximity to the supply bases in Japan and Commonwealth ships should operate on the west coast which was closer to British supply bases in Hong Kong and Singapore. When they arrived in the theater, the Canadian, Australian, and New Zealand naval forces would report to Admiral Andrewes. Captain Brock followed orders but considered it unfortunate that Canadian and U.S. naval forces would be separated because he thought they "could have learned a great deal from one another.",12

During the first week of August, British 6-inch cruisers Kenya and Belfast and accompanying destroyers bombarded the ports of Mokpo and Inchon on the west coast. In both instances, U.S. Navy P-2V Neptune patrol planes embarked Royal Navy officers who accurately spotted fire for the cruisers. ${ }^{13}$

The Canadian destroyers joined the naval effort on 31 August, one day after they arrived in Sasebo, Japan. Admiral Joy assigned the Canadian destroyers to Admiral Andrewes' task element, part of U.S. Rear Admiral C.C. Hartman's Blockade and Escort Force (Task Force 95). As her first duty, Athabaskan escorted a U.S. troopship transporting reinforcements to Pusan, the only port still held by UN forces. Cayuga's first mission was to

\footnotetext{
10 "First at Bat," 4.

11 Farrar-Hockley, The British Part in the Korean War, 73.

12 Quoted in Denis Stairs, The Diplomacy of Restraint: Canada, the Korean War, and the United States (Toronto: University of Toronto Press, 1974), 215.

13 Farrar-Hockley, The British Part in the Korean War, 77.
} 
protect an oiler refueling British and Dutch ships operating on the west coast. ${ }^{14}$

Soon however, the Canadian destroyers joined other U.S. and allied ships operating off the west coast to counter the enemy's southern advance and seaborne resupply efforts. Sioux operated three 4.7-inch guns in single turrets while Cayuga and Athabaskan were equipped with six 4-inch guns in three twin turrets. The guns were powerful, but the spotting systems used by the Canadians differed from those of the Americans and British. The Canadians soon developed a 'unique spotting disk' that enabled coordinated operations with the allied navies. In the words of the official history, "ultimately experience provided the remedy [to naval gunfire problems], and the Canadian destroyers built a reputation for providing prompt and accurate shooting." 15

Cayuga's opening action occurred on 15 August 1950, when she and a British frigate bombarded a small port occupied by the enemy west of Pusan to prevent its use as a supply base. With the assistance of a spotter plane from British carrier Theseus, the two warships hit the port with 94 rounds. Later in August, British cruiser Kenya and Canadian destroyers Sioux and Athabaskan bombarded coastal targets and the latter ship even put landing parties ashore to attack exposed enemy positions.

On occasion, members of the maritime 'band of brothers' helped their colleagues better understand and cope with directives from the army-heavy command structure. General MacArthur assumed that since allied air power had cut Communist supply lines ashore supplies were still getting through - it had to be coming in by sea. He put pressure on Admiral Joy, and thus on Admiral Andrewes, to improve the effectiveness of the west coast blockade. After meeting with Joy in Tokyo on 7 August, Andrewes recorded this observation:

Frequent reports from returning aircraft indicate that large numbers of Junks are sighted, here one day, there another. Immediately it is thought that they are a 'supply armada'. A ship goes [to the scene], a number are searched, they are found harmless... So I feel, and Admiral JOY really intimated, that he is continually faced with doubts about the blockade on both sides [of Korea] but more especially the West. He said plainly that 'he understood completely' but that it was hard to convince the Commander-in-Chief. The enemy was still getting supplies. All roads and bridges, railways and rolling stock had been knocked out by air, but still supplies were getting in. It must be by sea. Of course I could not deny the likelihood of some sea supplies evading the very thin patrols we have had. But still I do not think it is much. ${ }^{16}$

Nonetheless, to satisfy MacArthur, and with Joy's concurrence, on 12 August Andrewes ordered light carrier Triumph to sortie from Sasebo and stiffen the west coast blockade. Escorting the carrier were British cruiser Ceylon and destroyer Comus and Canadian destroyers Athabaskan and Sioux. On one occasion, aircraft from Triumph attacked and damaged several vessels located between Inchon and Chinnampo, but the effort hardly seemed to warrant the diversion of vital air resources. Andrewes concluded that "with the

14 "First at Bat," 4.

15 Quoted in "First at Bat," 7.

16 Quoted in "First at Bat," 8. 
lack of sea traffic, lack of serviceable shipping in port and general lack of activity, any supply running by the enemy down the West Coast must be on a very small scale."17

A common, if undesirable mission for UN destroyers was to steam in the protective screen around the British and American carriers. According to the official Canadian history:

The Canadians in Korea not only found the work tedious, but the constant manoeuvring to keep station as the carrier turned into the wind to launch and recover aircraft and then shifted back to base course was a bane to watchkeepers, signals staff, helmsmen and engine room personnel. Everyone had to stay on their toes lest their ship suffer the embarrassment of being caught out of position or, worse still, caused a collision. ${ }^{18}$

But, able to compare the British and American operational procedures, the Canadians chose what they considered the most feasible approach. Captain Brock persuaded the British to adopt the U.S. Navy's system in which the ships in the screen did not have to match every move of the carrier but steamed in the same general direction.

While combat between North Korean forces and UN ground troops fighting to hold the 'Pusan Perimeter' largely determined the outcome of the battle in July and August of 1950, air and naval support by UN navies was vital. Without that support, the North Korean army would have crushed UN forces or compelled a bloody withdrawal like the World War II evacuation of Dunkirk. Fighting side by side with the U.S. Navy in the war were naval forces from Great Britain, Australia, Canada, and New Zealand as well as Columbia, France, Holland, and Thailand.

\section{Amphibious Assault at Inchon}

Command of the sea was a distinct advantage for the United Nations Command, enabling General MacArthur and allied forces to reverse the tide of battle in Korea. U.S. Vice Admiral Arthur D. Struble, dual-hatted as Commander Seventh Fleet and Commander of Task Force 7, led 230 U.S., British, Australian, Canadian, Dutch, and French naval vessels in the amphibious assault on the North Korean-held port of Inchon in mid-September 1950. Admiral Joy appointed Rear Admiral Andrewes as commander of the Blockading and Covering Force (Task Force 91), which comprised a light carrier, a cruiser, eight destroyers, and fifteen Republic of Korea Navy submarine chasers and minesweepers. Captain Brock commanded the three Canadian destroyers and a number of South Korean combatants in the Blockade Force, Southern Group.

On 13 September, two days before the main assault at Inchon, British frigate Whitesand Bay landed a party of U.S. soldiers, Royal Marines, and Royal Navy sailors near Kunsan on the west coast. Their object was to draw the enemy's attention away from Inchon to the north. As intended, the troops ashore got into a hot firefight with the North Koreans. Before daylight most of the men returned in their rubber dinghies to the ship but nine of the Americans were missing. Lieutenant Commander J.V. Brothers, Whitesand Bay's skipper, refused to leave without the missing men even though his ship, her crew, and the soldiers and marines would be in great danger at daybreak from enemy shore batteries and aircraft. At the

$\begin{array}{ll}17 & \text { Quoted in "First at Bat," } 9 . \\ 18 & \text { Quoted in "First at Bat," } 9 .\end{array}$ 
last minute, seven of the Americans made it back to the ship, where they reported one of their comrades dead and another wounded ashore. The frigate immediately headed for the open sea and reached a safe distance from the shore as the sun rose in the sky. But for the Royal Navy officer's cool courage, it is likely the Americans would all have been killed or captured. $^{19}$

That same day, 13 September, British cruisers Jamaica and Kenya and U.S. cruisers Rochester and Toledo followed six American destroyers up Flying Fish Channel toward Inchon. The destroyers accomplished their mission of drawing enemy fire - several of them sustained hits and casualties - so the cruisers behind them could take out the North Korean shore batteries. The task force returned the following morning to ensure the enemy's guns on the island of Wolmi Do in the harbor were destroyed. The enemy exacted some revenge three days later when two North Korean planes strafed Jamaica and killed a sailor.

In the early morning of 15 September 1950, U.S. Seventh Fleet landing craft disembarked elements of the 1st Marine Division on Wolmi Do. After several days of hard fighting and reinforcement by other 1st Marine Division, South Korean, and U.S. $7^{\text {th }}$ Infantry Division troops, the allies captured the port and nearby Kimpo airfield. Less than a week later, UN ground forces that had broken out of the Pusan Perimeter linked up with the Inchon beachhead. By the end of September, after bloody, exhausting street-to-street fighting, the Marines seized Seoul, the South Korean capital. The masterful Inchon landing forced the badly hurt North Korean army to flee north across the 38th parallel and brought about the liberation of South Korea.

While these operations were underway, allied naval units ousted enemy forces from the area around Kunsan on the west coast below Inchon. On 23 September, Athabaskan and a ROK Navy vessel entered the small port of Poryon-po and poured fire into enemy gun positions, warehouses, and junks. Several days later, Athabaskan and Australian destroyer Bataan bombarded the island of Youjiki do. To ensure accurate naval gunfire, Canadian Lieutenant Commander C.A. Sturgeon moved a small boat close inshore and from there directed the fire of both ships by radio. The destroyers systematically destroyed one target after another. On 28 September, the final day of the operation, the Canadians spotted a large number of civilians digging trenches and other fighting positions. Athabaskan opened fire at a distance. A Canadian naval officer commented that "the United Nations policy of avoiding [civilian] casualties was made easy on this occasion by the white clad Koreans themselves who displayed more speed than dignity in clearing the area long before the first salvo landed." 20

A threat surfaced that would vex all allied naval operations - sea mines. Prior to a 25 September attack on Kunsan, the Canadians spotted a mine in the channel to the port. Boats sent out from Athabaskan discovered two more of the lethal weapons. The Canadian commander observed laconically that "that rather put me off going into the river." ${ }^{21} \mathrm{He}$ used his radar to find all the mines in the approaches and waited until the tide went out to shoot up

19 Farrar-Hockley, The British Part in the Korean War, 149.

20 Quoted in "First at Bat," 15-16.

21 Quoted in "First at Bat," 16. 
and destroy the exposed weapons. The following day, an enemy mine severely damaged the U.S. destroyer Brush, killing or wounding 47 American sailors. Captain Brock understood that the recent minelaying on both coasts by the North Koreans, with Soviet help, "has cast a new light on Naval warfare, and has demonstrated conclusively the power that mines have of stopping coastal shipping." 22

Despite the mines, U.S. and Commonwealth sailors and commanders accomplished their mission during the Inchon assault with bravery and professional skill. Admiral Sir Patrick Brind, British Commander in Chief of the Far East Station, reported to the First Sea Lord in London: "I have seen General MacArthur, Admirals Joy and Struble, and spent four days at Sasebo. From what I have seen myself and heard on all sides, the Commonwealth ships under Andrewes have met all calls made upon them exceedingly well and have made a great reputation for themselves."23 With typical verbal flair, General MacArthur sent Andrewes "my heartiest felicitations on the splendid conduct of the Fleet under your command. They have added another glamorous page to the long and brilliant histories of the Navies of the British Commonwealth." 24

\section{From Wonsan to Chinnampo: Attack and Withdrawal}

Communist-laid mines would continue to impact negatively on MacArthur's campaign plans. The general hoped to complete the destruction of the North Korean army and liberate all of Korea following another amphibious assault at Wonsan on the Sea of Japan. Once allied naval forces had landed Lieutenant General Edward "Ned" Almond's X Corps at Wonsan, the ground forces would advance to the Yalu River that bordered China and the Soviet Union. Fast-moving South Korean troops, however, liberated Wonsan on 10 October, a week before the planned landing, as did Bob Hope's USO troop.

The allies also discovered that the Communists had filled Wonsan Harbor with between 2,000 and 4,000 Soviet-made magnetic and contact mines. The U.S. Navy and ROK Navy lost three minesweepers to these mines before opening a passage to the port. Meanwhile, allied sailors, soldiers, and marines of the invasion armada complained about endless steaming around off Wonsan in what some called Operation "Yo Yo." Canadian Commander Robert P. Welland reported that the operation was characterized by "one anticlimax after another." 25 Perhaps with tongue-in-cheek, Captain Brock observed that Athabaskan had gained "much valuable experience in fleet work ... on a scale never likely to be duplicated in peacetime operations." ${ }^{26}$ At last, on 25 October 1950 the $1^{\text {st }}$ Marine Division and the other X Corps elements landed and advanced into the foreboding mountains of North Korea.

At the same time, the U.S. Eighth Army and associated allied ground forces raced pell-mell into North Korea and headed for the Yalu River. From General MacArthur on down, there was an expectation that the war would be over and the troops would be home by

\footnotetext{
22 Quoted in "First at Bat," 17.

23 Quoted in Farrar-Hockley, The British Part in the Korean War, 157.

24 Quoted in Farrar-Hockley, The British Part in the Korean War, 156.

25 Quoted in "First at Bat," 18.

26 Quoted in "First at Bat," 18.
} 
Christmas. Admiral Andrewes concluded that "preliminary arrangements could be made to release a part of the British, Commonwealth, and Allied ships employed on the West Coast of Korea." 27 The disintegration of the North Korean army had already prompted the departure for Hong Kong of British carrier Theseus and cruiser Kenya.

Then, on 25 November the Chinese People's Volunteer Army emerged from the frigid and snow-covered mountains of North Korea, where they had hidden for over a month, and smashed into the surprised allied divisions, driving them south in disorder.

Allied naval commanders made plans to evacuate the retreating troops from Inchon and Chinnampo, the latter Pyongyang's port. U.S. Rear Admiral Thackry was charged with commanding operations at Inchon. His countryman, Captain S.G. Kelly, was responsible for the withdrawal from Chinnampo, located at the head of a shallow, narrow, curving channel to the sea. Covered by carrier Theseus, the cruisers and destroyers of Read Admiral Andrewes' force were directed to support the evacuation. Canadian Captain Brock's task element, responsible for one operational sector, was made up of Cayuga, Athabaskan, Sioux, Australian destroyers Warramunga and Bataan, and U.S. destroyer Forrest Royal.

On 4 December, learning from Captain Kelly that the situation in the port of Chinnampo was approaching an emergency, Captain Brock ordered the commanding officers of his destroyer force to make a nighttime passage upriver to be on hand to protect the transports the following morning. Even though the river had been swept for mines, this was a risky proposition. On this pitch-black night, Warramunga and Sioux hit bottom in the shallow river, barely managing to work free of the mud and retire out to sea. Brock's reduced command pressed on, with the navigation officers of Cayuga and Athabaskan employing their considerable navigational skills and a new high-definition navigational radar to safely negotiate the passage.

The sense of urgency that prompted Brock's nighttime passage was nowhere in evidence when his force reached the port. The Chinese army was still miles away. This understanding led to harsh words from the Canadian commander, especially when American Captain Kelly suggested they meet "after breakfast." According to one source, "that made old Brock pretty furious, I'll tell you." ${ }^{28}$ Despite this contretemps, by evening the allies had embarked 7,700 soldiers and an untold number of refugees in the evacuation flotilla, which then proceeded downriver without incident. Shortly afterwards, the allied warships opened fire on the port facilities, destroying railway yards, oil tanks, supply dumps, and factories. The multinational naval force, which included three ROK Navy minesweepers, then safely made for the sea.

Admiral Andrewes informed Brock that the operation was "a fine feat of seamanship on the part of all concerned, and its bold execution was worthy of the finest traditions of the naval service." ${ }^{29}$ The command was especially impressed with Brock's performance, and he was made a member of the Distinguished Service Order. Other Canadian officers were decorated for their superior leadership and operational skill. In the words of the official

27 Quoted in "First at Bat," 21.

28 Quoted in "First at Bat," 24.

29 Quoted in "First at Bat," 26. 
history, “Chinnamp'o marked a professional high point in seamanship and was perhaps the RCN's finest moment in the Korean War."30

\section{Winter Withdrawal from Northeast Asia}

Control of the sea by the UN navies proved a plus to the allied cause not only in battlefield success but failure. That failure occurred when the Chinese People's Volunteer Army, much as it had on the western side of the peninsula, pounced on General Almond's X Corps around the Chosin Reservoir deep in the snow-covered mountains of North Korea. That massive assault compelled the $1^{\text {st }}$ Marine Division, British naval commandos, and U.S. Army and South Korean army units to fight their way out of an ever-closing trap to reach the sea. Naval aircraft operating from U.S. carriers Philippine Sea, Valley Forge, Princeton, and Leyte, and several escort carriers heavily bombed and strafed Chinese troops massing on the withdrawing UN troops. As the allied forces debouched from the mountains and approached the coast, U.S. battleship Missouri, cruisers Rochester and St Paul, and numerous destroyers and rocket vessels put up a curtain of fire behind them. U.S. and UN surface ships fired over 23,000 shells and rockets at Communist units bold enough to press toward Hungnam, the evacuation port.

By the last week of December 1950, U.S. Rear Admiral James Doyle's Amphibious Task Force (Task Force 90) had completed the withdrawal by sea of 105,000 troops, 91,000 civilian refugees, 350,000 tons of cargo, and 17,500 military vehicles. On 24 December, U.S. Navy demolition teams destroyed the port facilities at Hungnam to deny them to the Communists, and the UN fleet steamed south. After a short period for rest and refitting, the units withdrawn from North Korea with most of their equipment were back in the fight for South Korea. ${ }^{31}$

\section{Static War}

After a year of rapid movement up and down (or perhaps down and up) the Korean peninsula, the war settled generally along the $38^{\text {th }}$ parallel. This phase of the conflict lasted for two and one half bloody years until the belligerents signed an armistice agreement on 27 July 1953. During that time, the contending UN and Communist forces fought bloody pitched battles, in a manner similar to that of the trench warfare of World War I, for seemingly worthless pieces of real estate.

At the political level, allied solidarity was sorely tested during this phase. The British in particular frequently expressed their displeasure over General MacArthur's public statements in favor of air attacks on the People's Republic of China, a naval blockade of the China coast, and other measures that would have ignited a full-scale war with the PRC, if not the Soviet Union. Moreover, President Truman's public suggestion that atomic weapons might have to be used in Korea did not sit well with America's allies. And London bridled at U.S. military actions taken outside of the Korean theater along the China coast.

The British were not pleased with Truman's deployment of the Seventh Fleet in the Straits of Taiwan and support for Chiang Kai-shek's government after June 1950, since

30 Quoted in "First at Bat," 26.

31 Marolda, "U.S. Navy," in The Korean War: An Encyclopedia, 243. 
London had earlier recognized the People's Republic of China. On separate occasions in 1951 and 1952, Washington ordered the cruise of U.S. carrier task forces along the coast of China as far south as Hainan Island to discourage aggressive Chinese Communist behavior outside the Korean war zone. These cruises, in which U.S. naval aircraft overflew Chinese ports and American military spokesmen alluded to the U.S. fleet's ability to use 'baby atomic bombs' against China's coastal cities, were not appreciated in London. ${ }^{32}$

\section{Allied Naval Air Forces}

In contrast to the interaction between U.S. and Commonwealth political leaders, naval commanders continued to operate with remarkable equanimity. The military leaders were determined to prevent the Chinese and North Koreans from supplying their forces on the front line with heavy weapons, ammunition, supplies, and construction materials. The Seventh Fleet's Task Force 77, which consisted of large-deck aircraft carriers (eleven ships served in the Korean War) and Task Force 95 (one light and four escort carriers) did the heavy lifting for the United States. Navy combat squadrons operated from the carriers and Marine aviation units flew from both the escort carriers and shore bases. The fleet's fighter squadrons vied for control of the air with hundreds of Communist MiG-15 jets and other combat aircraft flown by North Korean, Chinese, and even Soviet air crews.

The Royal Navy posted aircraft carriers Triumph, Glory, Theseus, and Ocean to the Korean theater. Australia provided Sydney, the only other Commonwealth carrier. The light carrier's Sea Fury and Firefly aircraft took part in many of the air operations launched from the Yellow Sea and Sea of Japan, conducting 2,366 sorties for the loss of three pilots and thirteen aircraft. Indispensable to Sydney's successful operations was the flying skill of her naval aviators, three quarters of whom were World War II veterans, and the training and leadership provided by the Royal Navy. British officers on loan led the air group and its two combat squadrons. ${ }^{33}$

The Korean War experience also provided the Australian navy with its first opportunity to assess the value of shipboard helicopters for search and rescue operations. The U.S. Navy loaned Sydney a Sikorsky helicopter and a pilot, Chief Aviation Machinist's Mate A.K. Babbitt. In one dramatic operation, Babbitt used his helicopter, protected by escorting Australian Fireflys, to retrieve two Australian aviators from a plane downed in Korea. The rescue planes finished their dangerous mission in darkness and with fuel gauges registering empty. This and other successful missions, according to one historian, "encouraged the RAN to acquire its own helicopters" and establish its first operational squadron. ${ }^{34}$

\section{Interdiction and Close Air Support}

The most numerous air operations of the war involved attacks on the enemy's rear area resources and troop units. The attack squadrons focused their attention on Communist locomotives and rolling stock, supply depots, bridges, tunnels, and power-generating dams on the Yalu River. Providing responsive close air support to soldiers and Marines on the front

32 Marolda, "Sea Power and the Cold War in Asia," 172-73.

33 Cooper, "The Korean War Era," in Stevens, 177.

34 Cooper, "The Korean War Era," in Stevens, 178. 
line was another critical responsibility of the carrier and shore-based units. By the end of the war, U.S. naval air crews had flown 275,000 sorties over Korea, which represented 53 percent of the close air support strikes and 40 percent of the interdiction missions flown by U.S. Air Force, Navy, and Marine Corps planes. Naval aircraft dropped more than 178,000 tons of bombs, triggered over 274,000 air-to-ground rockets, and fired more than 71 million cannon rounds. ${ }^{35}$

When the three Canadian destroyers joined up with Task Force 77, they found the experience an 'eye opener' since the big American fleet carriers moved at a higher rate of speed than the Commonwealth carriers on the west coast. Station-keeping and underway replenishment operations posed particular problems. On the other hand, the Canadians benefited from the opportunity to observe jet operations from the American flattops.

One Canadian gained especially valuable experience flying F9F Panthers from carrier Oriskany. Lieutenant J.J. MacBrien, attached to U.S. Fighter Squadron 781 (VF-781), was awarded the Distinguished Flying Cross by the Americans for his "courageous leadership and outstanding demonstration of pilot skill." 36 The Commonwealth navies often returned the favor. New Zealand Midshipman C.J. Steward, serving on board British carrier Glory, remembered an episode when U.S. light carrier Bataan suffered a flight deck accident that prevented returning U.S. Marine aircraft, low on fuel, from recovering on board. Glory immediately cleared her own flight deck so the Marines would not have to ditch in rough seas. $^{37}$

\section{Thunder from the Sea}

The projection of naval power ashore came from another source - allied battleships, cruisers, destroyers, and rocket vessels. Naval gunfire support was certainly welcomed by allied soldiers and marines facing Chinese 'human wave' assaults. The UN naval force moved along the Korean coast bombarding North Korean railways, roads, supply caches, and troop concentrations. On many occasions, U.S. and Commonwealth warships teamed up for these bombardment operations. Postwar estimates credited UN surface warships, which fired 4 million rounds of naval gun ammunition, with killing tens of thousands of enemy troops, and destroying many buildings, trucks, bridges, and supply dumps. Enemy counter-battery fire failed to sink even one UN warship.

There were occasional disagreements over the employment of naval gunfire. At one point, British Admiral Andrewes observed that he was "a little worried about wastage of ammunition through ships carrying out what might be termed 'casual' bombardment. ... An unplanned and unobserved bombardment is not of great value." He was also concerned that such gunfire might unnecessarily damage South Korean property. ${ }^{38}$ Other Commonwealth commanders alluded to the profligacy of the Americans on the gun line but this complaint was certainly not unique to the Korean War.

The U.S. and Commonwealth navies, however, seldom experienced serious

35 Hallion, "Naval Air Operations in the Korean War," in The Korean War: An Encyclopedia.

36 Quoted in "Islands and Packages."

37 Hopkins, Tales From Korea, 45.

38 Quoted in "First at Bat," 16. 
difficulties operating as a team on naval gunfire missions. During one period in the spring of 1951, when U.S., British, Australian, and Canadian ships attacked enemy targets on the east coast around Wonsan, the commanding officer of Canadian destroyer Athabaskan reported as follows: "This international force ... worked together ... in near perfect harmony. ... There were no inter-service difficulties that affected the efficiency of operations. Communications were good, manoeuvring [sic] was rapid and correct, [and] fueling and storing was carried out from both British and U.S. logistic ships. Command relationships were excellent." ${ }^{\text {"9 }}$

The enemy moved supplies on the rails and roads of North Korea, some of which hugged the coast and thus were vulnerable to naval gunfire. In July 1952, U.S. destroyer Orleck shot up two trains in a twelve-day period. To boost morale, the staff of Task Force 95 started a 'Trainbusters Club' and opened a competition to see which UN ship could eliminate the most North Korean trains. During the next year, eighteen 'members' of the club had destroyed twenty-eight trains. According to the official Canadian history, destroyer Crusader was "recognized as the undisputed champion of the club."40

The enemy, however, was hardly toothless. During a bombardment mission near Songjin in October 1952, fire from a North Korean shore battery struck Canadian destroyer Iroquois, in company with U.S. destroyer Marsh, killing Lieutenant Commander John L. Quinn, Able Seaman Elburne A. Baikie, and Able Seaman Wallis M. Burden, and wounding ten other men. ${ }^{41}$

As was common during this period, some American and New Zealand officers and men served temporarily on board the warships of their allies. The Americans appreciated access to the rum ration on the Commonwealth ships and the New Zealanders gloried in the "absolutely first class American food." On one occasion, New Zealand frigate Taupo joined the U.S. destroyer Endicott for a bombardment mission on the east coast near Yang Do. On Endicott's bridge during the operation, New Zealand Lieutenant J.P.D. Hall observed the interaction between the ship's executive officer and the captain as enemy shells straddled the destroyer. The exec exclaimed, "Gee, Captain, these salvoes are getting closer; Captain, they're getting closer!" The captain turned to the subordinate, took a cigar slowly out of his mouth, and said: "What the goddamned hell do you expect me to do, submerge?" The visitor from New Zealand admired the sang froid of the American skipper. ${ }^{42}$

On the night of 23 October 1952, Canadian destroyer Crusader teamed up with U.S. destroyer DeHaven to work over a North Korean train that hid in a tunnel but when it emerged was caught by the guns of the UN warships and worked over good. The following morning attack planes from Task Force 77 arrived to finish the job. The surface-air team totally destroyed the enemy supply train and much of the track on which it tried to move. ${ }^{43}$

On another occasion, the commanding officer of Crusader allowed a U.S. Marine officer, temporarily on board, to operate from one of the destroyer's small boats close to the

39 Quoted in Stairs, The Diplomacy of Constraint, 217.

40 Quoted in "Islands and Packages."

41 "Islands and Packages."

42 Quoted in Hopkins, Tales From Korea, 123-24.

43 "Islands and Packages." 
shore where he listened for the sound of approaching trains. When he heard one, the American Marine called in fire from the destroyer that, combined with an air attack, destroyed the enemy train. ${ }^{44}$

There was no question that the comprehensive air effort, with its supporting surface force bombardment operations, denied the Communists critical supplies and saved the lives of thousands of allied soldiers battling at the 38th parallel - but it did not sever the enemy's supply lines or stop him from launching massive offensives. An army of North Korean civilians and military engineers repaired bombed rail lines, bridges, and supply depots. Nighttime often hid Communist supply movements. Moreover, enemy air defenses brought down hundreds of UN aircraft. The Korean War experience showed that in this new era of 'limited war', air power would be an important, but certainly not decisive weapon.

\section{Sea Control and Blockade}

Throughout the Korean War, U.S. and allied naval forces denied the enemy use of the sea to transport troops and supplies. Control of the sea also allowed the UN command to threaten other amphibious landings in the rear of the Communist armies fighting along the $38^{\text {th }}$ parallel. Burned once at Inchon, the enemy took the threat seriously and deployed large units along both coasts, where they posed no danger to UN troops on the front line. The British commander of Commonwealth naval forces observed that the enemy appreciated the threat because of the "large number of troops the enemy has had to disperse in a purely defensive role over the past year [1952-1953]. On the West Coast alone these forces have been increased from about 40,000 to approximately 80,000 - forces which otherwise could have been employed in the battleline." 45

To keep the enemy guessing, the allied naval forces conducted several feints and demonstrations. In Operation Decoy during October 1952, for instance, Seventh Fleet carriers, battleships, cruisers, and destroyers attacked Communist defenses around Kojo and the amphibious force operated as if to land the Army's $1^{\text {st }}$ Cavalry Division near Wonsan. The Chinese and North Koreans rushed forces to the coast to defeat the non-existent amphibious assault.

The allied navies also used control of the sea to blockade the coasts and garrison islands with special operations forces and guerrilla bands that harassed the enemy's flanks. The blockade of Wonsan from 16 February 1951 to the end of the war denied the Communists use of North Korea's most important port on the east coast. From islands and from naval vessels at sea, U.S. Navy underwater demolition teams or 'frogmen', U.S. Marines, and British and South Korean naval commandos carried out many successful sabotage missions against highway bridges, supply dumps, railroad tracks, and railroad tunnels behind enemy lines. The occupied islands in the west, on which were emplaced SHORAN [SHOrt RAnge Navigation] and radio equipment, were critical to the U.S. Air Force's bomber and fighter missions near the Yalu in 'MiG Alley'.

In July 1951, Australian frigate Murchison, New Zealand frigate Rotoiti, and other Commonwealth warships moved in and out of the Han River estuary to bombard land still

44 "Islands and Packages."
45 Quoted in "Islands and Packages." 
occupied by the Communists south of the $38^{\text {th }}$ parallel. It was also hoped that the sound of this naval gunfire would be heard by the Communist military representatives at nearby Kaesong and influence their deliberations with their UN counterparts. The officers at Kaesong heard the sounds but enemy shore batteries damaged Murchison and wounded a sailor, prompting an evaluation of the operation's value. ${ }^{46}$

Commonwealth warships frequently worked with U.S. special forces and South Korean guerrillas in the shallow waters of the west coast. In July 1951, Royal New Zealand Navy frigate Rotoiti put a landing party of sailors ashore that captured two North Korean soldiers. The following month, with Rotoiti in support, Royal Navy cruiser Ceylon landed Royal Marines on the coast who traded fire with the enemy and successfully withdrew to the ship.

Canadian destroyer Cayuga, equipped with an advanced Sperry radar, proved to be one of the stars of the west coast inshore patrol. On board was Brock's replacement as commander of the Canadian destroyer flotilla, Commander James Plomer. On one occasion, Cayuga moved to within 2,500 yards of shore to provide gunfire support to a unit of South Korean guerrillas pinned down on the beach. During the same period, Sergeant Frost, a U.S. Army special operations warrior, embarked in the destroyer and identified targets for the warship. After one mission, according to the Canadians, Frost "was well pleased with the days work." ${ }^{47}$

The allied navies did not always see eye to eye. The British were not keen about extensive shelling of enemy territory as ceasefire negotiations were underway at Panmunjom and preferred, according to Plomer, a 'go easy' approach. In September 1951, during a guerrilla raid involving Canadian naval and South Korean ground forces, the allies killed 170 of the enemy. According to Plomer, "I was received on the return to harbour in an atmosphere of strong disapproval. [Royal Navy Rear Admiral A.K. Scott-Moncrieff] said to me 'we do not want to upset these people' [that is, the enemy]." Other reports had Moncrieff concluding that the operations on the west coast were "a great waste of effort and a drain on the British economy." 48

Rear Admiral George C. Dyer, the U.S. commander of Task Force 95, sceptical about the promise of the peace talks, took a different tack and according to the Canadians "consistently followed an aggressive war-like policy."49 Apparently there were other bones of contention between the British and Americans. The official Canadian history recounted that "sniping apparently became quite poisonous and Plomer deprecated the constant criticism directed by certain British staff officers at their American allies, some of it quite openly." ${ }^{50}$ In the end, according to the official history, the "actions of the commanding officers of Canadian ships in Korea demonstrate that they agreed with Dyer's strategy; they were at war and

\footnotetext{
46 Cooper, "The Korean War Era," in Stevens, 174-765.

47 Quoted in "First at Bat."

48 Quoted in "Islands and Packages."

49 Quoted in "Islands and Packages."

50 Quoted in "Islands and Packages."
} 
wanted to keep the pressure on the enemy." ${ }^{51}$ As an example of continued Canadian derringdo, on 22 September 1952 destroyer Nootka surprised and captured a North Korean minelayer among the islands. ${ }^{52}$

Other less serious disagreements occurred between the sailors of the U.S. and Commonwealth navies. New Zealand Engine Room Artificer W.S. Watson observed that "my first memories of Japan [were] of Americans, prostitutes, and canteens." He groused that the "Americans ... had more money, were more blasé about it, and there was more fighting," but added that in general "we got on very well with the Americans., 53

\section{Sealift and Logistics}

For UN naval and military forces to fight successfully on a peninsula 5,000 miles from the United States and even further from other allied countries, required a massive seaborne supply operation. Hundreds of troopships, freighters, and tankers were necessary to deliver the troops, tanks, artillery pieces, trucks, ammunition, and fuel demanded by the war effort. The U.S. Navy's Military Sea Transportation Service (MSTS) alone delivered 5 million passengers, more than 52 million tons of cargo, and 22 million long tons of fuel during the war.

Since the Canadian destroyers had no logistical capability of their own - Captain Brock characterized the RCN ships as "beggars and borrowers" - they had to rely on their American and British allies for resupply. They were not turned away. Arrangements were in place for the U.S. Navy to provide common logistical items and "such stores as the Royal Navy could spare were [unhesitatingly] placed at the disposal of H.M.C. ships." ${ }^{\text {"54 }}$ As detailed by another source, since both the British and the Americans used the logistic facilities at Sasebo, "the Canadians were able to milk their two main sources of supply at the same time. Some items were obtained indifferently from either American or British sources as dictated by convenience." ${ }^{, 55}$

An enormous task for the U.S. and Commonwealth navies was maintaining the major combatants on station and in the fight off Korea. U.S. and British fleet oilers, ammunition ships, and stores ships transferred their vital commodities directly to their nations' warships through underway replenishment or UNREP and routinely shared their largesse with Commonwealth units. The Canadians, for instance, acquired fuel "from the Americans in Sasebo, from British oilers in Korean west coast waters, and from American oilers in east coast waters. ${ }^{, 56}$

Deploying the three Canadian destroyers to Korea, according to the official history, was "straining the navy to the limit" and along with NATO commitments was "in danger of bankrupting the service." ${ }^{57}$ Nonetheless, the Canadians never shied from supporting the UN

\footnotetext{
51 Quoted in "Islands and Packages."

52 Cagle and Manson, The Sea War in Korea, 204-207.

53 Quoted in Hopkins, Tales From Korea, 28.

54 Quoted in "First at Bat," 19.

55 Stairs, The Diplomacy of Constraint, 218.

56 Stairs, The Diplomacy of Restraint, 218.

57 Quoted in "First at Bat."
} 
effort in Korea. It gave Canada some clout to restrain American actions. According to the official history, the deployment also "demonstrated that the RCN had a role in the post-war world" and "demonstrated Canada's strong backing of the UN. ... The Canadian destroyers played an important role in maintaining the United Nations' indisputable command of the sea and in supporting operations ashore." 58

In short, navies were essential to the UN effort in this first 'limited war' of the Cold War. Without these navies, and the sacrifices and dedication to duty of their sailors and marines, the UN would not have been able to achieve the war's primary goal - to maintain the independence of South Korea and its people.

The end of the Korean War in 1953 did not end the commitment of the Commonwealth navies to maintaining the peace in Northeast Asia. As late as 1957, British, Canadian, New Zealand, or Australian warships (including Australian carriers Sydney and Vengeance) continued to patrol in the seas around Korea in conjunction with U.S. Navy operations. $^{59}$

\section{Naval Cooperation in Southeast Asia}

Even with the Korean War underway, the Australian, New Zealand, and U.S. navies took a significant measure to coordinate their actions far from northeast Asia. U.S. Admiral Arthur W. Radford, commander of American military forces in the Pacific, and Rear Admiral John Collins, Australian Chief of Naval Staff, recognized the need for increased Commonwealth-U.S. cooperation and readiness for global operations. The Radford-Collins Agreement of early 1951 identified national areas of responsibility for anti-submarine warfare, ocean surveillance, and control of shipping in wartime. According to an Australian historian, the RAN "used the agreement to justify its force structure requirements until at least the early 1980s." 60 The Australian navy's attention to anti-submarine warfare, in keeping with the U.S. Navy's post-Korean War focus, provided the RAN with "important flow-on benefits, including privileged access to intelligence and advanced technology." During the 1950s and 1960s, the RAN "sought to introduce an anti-submarine helicopter, develop the Ikara missile system, and reintroduce a submarine arm, justifying all these improvements, at least in part, by the need to increase its ASW effectiveness."

Australia, New Zealand, and the United States also recognized the need for improved cooperation to counter the rising Communist threat. In September 1951, these nations signed the ANZUS Pact that provided for military and naval cooperation in southeast Asia. Then, in 1954 the United States, Great Britain, France, Pakistan, Thailand, Australia, New Zealand, and the Philippines established the Southeast Asia Treaty Organization (SEATO). The signatories pledged to oppose, by military force if necessary, Communist aggression in the region.

From 1954 to 1964, the SEATO navies exchanged officers, developed contingency

\footnotetext{
58 "Islands and Packages."

59 Hopkins, Tales From Korea, 25-26; Cooper, "The Korean War Era," in Stevens, 178.

60 Cooper, "The Korean War Era," in Stevens, 164.

61 Cooper, "The Korean War Era," in Stevens, 179.
} 
plans, and conducted maritime exercises. Exercise Pony Express in April 1961 involved various naval maneuvers off the coast of North Borneo. In 1963, U.S., Australian, and Philippines naval forces, totaling 70 ships, 400 aircraft, and 37,000 men, carried out Exercise Tulungan in the Philippines. The focus of the exercise was a SEATO response to a hypothetical invasion of Vietnam by Communist forces. ${ }^{62}$

Because of dwindling national resources in the 1950s and early 1960s, however, the British increasingly demonstrated an aversion to expanded military commitments in Asia, especially in Indochina. Only the Australians and Americans expressed deep concern about aggressive Vietnamese and Chinese Communist behavior in Indochina. As one example of Canberra's desire to strengthen its relations with Washington in the 1950s, instead of British warships the RAN acquired U.S.-made Charles F. Adams-class guided missile destroyers.

There was a deep reservoir of respect and admiration between the U.S. and Australian navies based on their joint experience in World War II and Korea. A reflection of that fact was the American naming of guided missile cruiser Canberra (CAG 2) after the Australian warship sunk along with three U.S. cruisers at the World War II Battle of Savo Island. In 1968 President Lyndon B. Johnson directed the naming of U.S. destroyer escort Harold E. Holt (DE 1074) after the Australian prime minister who had drowned in a seaside accident. Australia returned the favor by naming a naval vessel Wyatt Earp after the American Wild West town marshal and destroyer Bataan for the Americans who died on the famous 1942 'death march' in the Philippines. ${ }^{63}$

The relatively small RAN was fully engaged in southeast Asian operations during the volatile 1950s and early 1960s. In conjunction with British, New Zealand, and Malayan government forces, the Australian navy focused on defeating the Communist insurgency in Malaya. During 1956 and 1957 for instance, Australian warships Anzac, Tobruk, Quickmatch, and Queenborough bombarded Communist guerrillas in the jungles of Malaya. ${ }^{64}$ In succeeding years, Australia and its Commonwealth partners worked to frustrate the expansionist plans of Indonesia's Sukarno. British, New Zealand, Malaysian, and Australian naval vessels - 80 combatants at one point in the mid-1960s - were deployed in the South China Sea to counter Sukarno's aggressive behavior. ${ }^{65}$

\section{The Vietnam War}

The Commonwealth navies were clearly doing their part to counter Communist and nationalist violence in southeast Asia, so they were disinclined to take on additional work off Vietnam. Hence, in 1962 and again in 1965 when U.S. military leaders asked the Australians to deploy RAN warships to the South China Sea for joint American, Australian, and South Vietnamese anti-infiltration patrols, they declined. ${ }^{66}$

62 Edward J. Marolda and Oscar P. Fitzgerald, From Military Assistance to Combat, 1959-1965, Vol. II in series The United States Navy and the Vietnam Conflict (Washington: Naval Historical Center, 1986), 64-65, 285-86.

63 Dictionary of American Naval Fighting Ships.

64 Cooper, "The Era of Forward Defence," in Stevens, 182.

65 Jeffrey Grey, Up Top: The Royal Australian Navy and Southeast Asian Conflicts, 1955-1972 (Canberra: Allen \& Unwin, 1998), 2-56, 70.

66

Grey, Up Top, 74-77. 
The Vietnam War began in earnest in March 1965, when President Johnson ordered the deployment to South Vietnam of major U.S. combat units that would eventually total half a million men. Australian, New Zealand, South Korean, and Thai contingents joined the American and South Vietnamese ground forces. ${ }^{67}$ And this time, Canberra agreed to the deployment of RAN warships. The primary motivation was to provide a recognizable commitment to Australia's most vital global ally. ${ }^{68}$

Despite the desire for their warships to take part in the war, the Australians had to overcome significant obstacles. The U.S. Navy was expected to provide the RAN units with repair parts and other specialized logistic support, but most of the Australian ships, weapon systems, and equipment were of British origin. Remembering the positive Korean War experience, the Americans also asked Canberra to deploy an aircraft carrier off Vietnam. But since the RAN had long focused on anti-submarine warfare, it had neither an appropriate ship nor aircraft for interdiction and close air support operations. ${ }^{69}$

The Royal Australian Navy's fast troopship Sydney deployed the first Australian soldiers to South Vietnam in May 1965 and continued that transport mission until December 1972. In 1967, the RAN's Fleet Air Arm dispatched a squadron of helicopters to the Mekong Delta and deployed Clearance Diving Team 3 to Vung Tau and later Danang to assist the Americans with harbor defense and explosive ordnance disposal. The most visible symbols of Australia's naval commitment to Vietnam were the American-built Charles F. Adams-class guided missile destroyers Hobart, Perth, and Brisbane. Rounding out the quartet was Vendetta, an Australian-built destroyer. All but Vendetta completed two or three six-month deployments to Vietnam. ${ }^{70}$

All Australian forces in South Vietnam reported to Commander Australian Forces, Vietnam, who 'coordinated' with Commander U.S. Military Assistance Command, Vietnam. It was clear to both parties, however, that Australian forces would be guided by Canberra's foreign policy whether or not it coincided with Washington's. ${ }^{71}$ Aside from this political restriction, RAN units functioned under the operational control of U.S. commanders. U.S. Army headquarters directed the RAN helicopter squadron, U.S. Naval Forces, Vietnam (NAVFORV) guided Clearance Diving Team 3, and the Seventh Fleet oversaw the destroyers on the naval gun line. ${ }^{72}$

The Australian destroyers took part in bombardment missions in both North and South Vietnam. In Operation Rolling Thunder, naval aircraft from the U.S. carriers and from shore bases struck targets in North Vietnam in an effort to stem the flow of reinforcements and supplies to Communist forces in South Vietnam. In Operation Sea Dragon, a subset of

67 Jack Shulimson and Charles M. Johnson, The Landing and the Buildup, 1965, in series U.S. Marines in Vietnam (Washington: USMC History and Museums Division, 1978).

68 Dennis Fairfax, Navy in Vietnam: A Record of the Royal Australian Navy in the Vietnam War, 1965-1972 (Canberra: Australian Government Publishing Service, 1980), 17-18.

69 Grey, Up Top, 150-55, 169, 197, 229, 234.

70 Fairfax, Navy in Vietnam, 9-21.

71 Grey, Up Top, 96, 140-41.

72 Fairfax, Navy in Vietnam, 19-21. 
Rolling Thunder, U.S. and Australian warships steamed along the coast of North Vietnam shelling bridges, highways, ports, and water-borne logistic craft called 'WIBLICs'. American cruisers and destroyers armed with 8-inch, 6-inch, and 5-inch guns, and Australia's destroyers armed with 5-inch guns, forced the North Vietnamese to divert much of their logistic traffic inland away from the coast. ${ }^{73}$

American sailors frequently noted the courage and professional skill of their Australian counterparts. U.S. commanders adopted many RAN suggestions for improving tactics and techniques. It was not uncommon for Australian combat leaders to command U.S. and Australian task forces. The commanding officer of Perth remarked that his ship's operations off Vietnam allowed the RAN to "demonstrate both to ourselves and to others that we could fight this sophisticated weapon of war just as well as the Americans." "74 One historian concluded that "the experience of operating within the Seventh Fleet was enormously valuable for the RAN." Just as in Korea, the RAN thought the Seventh Fleet too wasteful with naval gunfire. Americans, however, made the same criticism of their own navy. ${ }^{75}$

At times, the sustained air and naval gunfire campaign reduced enemy logistic traffic in North Vietnam below the $20^{\text {th }}$ parallel to a trickle. But the enemy routinely took advantage of periodic U.S. ceasefires designed to 'give peace a chance' and reestablished their supply routes. And as in Korea, Communist coastal batteries hit the American and Australian ships on the gun line, killing and wounding sailors and damaging ships.

American, Australian, and Vietnamese naval forces also operated along the entire coast of South Vietnam bombarding enemy troops, fortifications, and supply caches. Frequently, allied warships prevented ground units from being overrun. An infantry officer in the U.S. $1^{\text {st }}$ Cavalry Division on one occasion praised the gunfire support from Hobart: "That was the best repeat best artillery support I have ever received - close enough to rattle my teeth and send shrapnel over our heads but extremely accurate."76

Like their compatriots ashore in Vietnam, American and Australian sailors suffered from so-called 'friendly fire' and other mishaps. One dark night in June 1968, U.S. Air Force pilots, thinking they were attacking an infiltrating North Vietnamese vessel, shot up Hobart, killing two Australian sailors and severely damaging the ship. The following June, U.S. destroyer Frank E. Evans, steaming with Australian carrier Melbourne in the South China Sea, turned in front of the larger ship and was cut in two. The destroyer's bow section went down along with 74 American crewmen. Despite these deadly mishaps, the strength of the U.S.-Australian bond and an understanding of the perils of sea duty enabled the two navies to carry on. ${ }^{77}$

The U.S. Navy and Royal Australian Navy performed their mission in the Vietnam War with skill and determination, but the impact of naval power on the struggle for Indochina

73 Edward J. Marolda, By Sea, Air, and Land: An Illustrated History of the U.S. Navy and the War in Southeast Asia (Washington: Naval Historical Center, 1994), 76-78.

74 Quoted in Grey, Up Top.

75 Grey, Up Top, 150-55, 169, 197, 229, 234.

76 Quoted in Grey, Up Top, 173.

77 Grey, Up Top, 175-88. 
did not equate to the contribution of the forces ashore. The latter determined the success or failure of guerrilla and counter-guerrilla operations, conventional battles, insurgency and counter-insurgency programs, and ultimately the war itself.

\section{Countering the Soviet Navy Threat}

America's retrenchment and partial drawdown of forces in the western Pacific after the Vietnam War proved to be short-lived. Faced with a growing Soviet military presence in the Asia-Pacific region in the late 1970s and early 1980s, U.S. and Canadian naval forces often took part in combined exercises in the Pacific. Sizeable and increasingly capable Soviet naval forces operating from Vladivostok and other military bases on the Kamchatka Peninsula challenged U.S. and Japanese Maritime Self Defense Force control of the sea in the North Pacific. Preparing to counter the Soviet threat, the U.S. and other navies frequently exercised various scenarios. At the end of 1982, for instance, U.S. Navy and Marine and Canadian forces practiced amphibious assaults on Amchitka in the western Aleutian Islands.

Coping with another concern, Soviet military forces operating from the naval base at Cam Ranh Bay in Vietnam, stimulated increased USN and RAN cooperative efforts. The Soviet invasion of Afghanistan in 1979 prompted Australia to deploy a multi-ship RAN task force on an extended show-the-flag cruise in the Indian Ocean. From 1980 to 1985, the RAN maintained in these same waters one or two destroyers or frigates. In the words of an Australian historian, "Australian involvement was coordinated with the United States, and the RAN's vessels invariably operated with the carrier battle group maintained in the area. Close encounters with Soviet forces took place regularly.",78

The United States and New Zealand had a parting of the ways in the last decades of the Cold War over the issue of nuclear power and weapons, but that disagreement never translated to any animus between the U.S. Navy-Royal New Zealand Navy, veterans of many Cold War actions.

To the end of the Cold War and beyond, Australian and Canadian warships took part in periodic U.S.-sponsored Rim of the Pacific (RIMPAC) exercises. In the words of an Australian historian, "the RIMPAC series gave the RAN a valuable opportunity to maintain its interoperability with the USN and to exercise sophisticated blue-water operations in a multi-threat environment." He added, "there was now no doubt about the RAN's dependence on American technology and knowledge, and the relationship with the USN continued to grow in a wide range of areas." $" 79$

It is hardly remarkable that in the $21^{\text {st }}$ century, the navies of the United States, Great Britain, Canada, and Australia have continued to jointly face and overcome the new challenges to Asian peace from terrorism, piracy, and the proliferation of weapons of mass destruction. The U.S. and Commonwealth navies built upon their especially valuable combined operations during the Korean War in particular and the Cold War in general to forge an enduring brotherhood of the sea.

78 Peter Jones, “Toward Self-Reliance,” in Stevens, 229.

79 Jones, "Toward Self-Reliance," in Stevens, 230. 